\title{
THE ANALYSIS OF TECHNICAL AND COST EFFICIENCY OF CULTURED FISH PRODUCTION IN KWARA STATE, NIGERIA
}

\author{
Akanbi, S. 0. \\ Technical \& Entrepreneurship Centre, University of Ilorin, P.M.B.1515, Ilorin, Nigeria. \\ Email:dipoakanbi@gmail.com
}

\begin{abstract}
This study was designed to analyse the Technical efficiency of cultured fish production in Kwara state, Nigeria. Specifically, the study estimated the technical efficiency of cultured fish farms; examined cost efficiency and long term elasticity of cultured fish production. The data used for this study were collected over one production cycle in 2013 using a well-structured questionnaire. A total of 63 respondents were drawn from a sampling frame of 121 registered cultured fish farmers through random sampling technique. Analytical tools used for the study was Stochastic Frontier Model (SFM). The findings of the study revealed that cultured fish farms in Kwara States operated with mean Technical Efficiency (TE) of 83.62\%; cost efficiency in cultured fish production among farmers was less than unity; long-run total cost elasticity of production was less than one in all cases implying that cultured fish production process in the study area is in the zone of increasing returns. The study therefore recommended that the government should facilitate a policy of reduction in the cost of inputs. A reduction in costs may lead to an increased output and thereby reduce the supply-demand gap for fish in the state. In addition, the fish farmers should be provided with the services of well-trained extension workers who will be there to guide them appropriately on production best practices to enable farmers improve upon farm efficiency.
\end{abstract}

Keywords: Technical efficiency, Cost Efficiency, Cultured fish Production and Kwara State

\section{INTRODUCTION}

The role of Agriculture in economic development has been recognized over the years and more importantly, the adoption of new technologies designed to enhance farm output and income has received particular attention as means to furthering economic development (Olayiwola, 2013). Output growths are however not only determined by technological innovations but also by the efficiency with which available technologies are used (Bravo-Ureta and Pinheiro 1993). As aptly posited by Rahii and Omotesho (2006) the production efficiency of any investment, particularly in the agricultural sector, is important for sustainability. They further submitted that the efficiency with 
which farmers use available resource and improved technologies is important in production, more so that the demand for food is increasing due to population increase.

Fish consumption, differs among countries, within countries and among segments of societies. These differences reflect inter-alia consumer preferences, availability, product developments, prices and levels of disposable income. The driving force behind the enormous surge in the consumption of fish is a combination of population growth, rising incomes, health issue, increasing awareness and urbanization (World Bank, 2010). Three primary sources of fish are available to consumers in Nigeria. These are inland waters stock, cultured fish production and fish importation. Statistical data (CBN, 2011) reveal that the overall yield from inland waters fish production in Nigeria has over the last decade increased at the rate of $14.76 \%$ per annum; open water fish production has also increased by $8.17 \%$ per annum and catches from closed water have risen by $6.5 \%$ per annum (FMARD, 2011). Furthermore, the Federal Department of Fisheries (FMARD 2011) puts the total Inland Aquaculture production at 152,796 metric tonnes and total annual capture fish production at 541,368 metric tonnes. This puts Nigeria on the frontline in terms of Aquaculture production in the continent. There was no much difference in domestic fish production in years 2006 and 2007. But in years 2008 and 2009 total domestic fish production rose to 684,575 MT and 780,704 metric tons respectively (FMARD 2011). However, domestic national demand is put at about 1.5 million metric tonnes. There is thus a shortfall of about 700,000 to 900, 000 metric tonnes (FMARD 2011).. The resultant effect of this shortfall is the importation of about 937,428 MT of fish. This amounts to more than $\$ 400$ million being spent and of course, thousands of job opportunities lost to exportation. With increasing population and diminishing returns in the capture fisheries, there has been a shortfall in the available fish stock, necessary to meet the local consumption's demand (FAO, 2010). The fishery sub-sector is one of the agricultural sectors which by all means has not been given the desired priority and which by all standards is capable of bridging the gap in the daily protein dietary needs of a constantly growing population. Nigeria's per capita daily protein intake is estimated to be $45.4 \mathrm{~g}$ as against the FAO minimum $53.8 \mathrm{~g}$ (lyangbe and Orewa, 2009) Hence, this study on the efficiency and productivity of cultured fish farms in Nigeria, will no doubt show the magnitude of gains that could be obtained by improving performance in production. The study stands to provide empirical measures of efficiency that will help in the reduction of the production cost in Kwara State of Nigeria (Kwara MANR, 2012) In the light of the fore-going, this study sought to provide answers to 
the following research questions:

- Are the emerging cultured fish farms technically efficient?

- How cost efficient is cultured fish production in the study area?

- What is the long-run cost elasticity of cultured fish production?

Objective of study

1 estimate the technical efficiency of cultured fish farms in the study area

2 determine the cost efficiency in cultured fish production in the study area

3 determine the long-run total cost elasticity of cultured fish production in the study area.

\section{Theoretical Framework}

The framework for the study is developed from interplay of the theory of agricultural production and efficiency in cultured fish production. According to Khandaker (1998), efficiency is a very important factor of productivity growth. In an economy where resources are scarce and opportunities for new technologies are lacking, inefficiency studies will show that it is possible to raise productivity by improving efficiency without increasing the resource base or developing new technology. It also helps determine the under-utilization or over utilization of factor inputs. Schmidt (1986) asserted that a production function can be estimated from observed outputs and the level of inputs used and defines the average level of outputs for a given set of inputs. Production functions are used in the cases of individual firms for estimating relative contribution of factors of production, including Cobb-Douglas production function, Squires (1987). Farrell's measure of efficiency assumed the existence of an efficient production function with which the observed performance of a firm could be compared. A production function based on the "best" practical results would have to be used as a reference for measuring an individual firm's performance. Hence, for practical purposes, Farrel (1957) suggested that it was better to compare actual performance with a "best" obtained result than with an unrealizable ideal.

\section{RESEARCH METHODOLOGY}

\section{The Study Area}

Kwara state shares boundaries with Oyo, Osun and Ekiti to the South, Kogi and Niger to the North, Kogi to the east and Republic of Benin on the west side. The State which happens to be located in 
the North-Central Geo-political Zone of Nigeria has sixteen Local Government Areas. It has an estimated population of about 2.3 million people (NPC 2006), a figure which is assumed to have substantially increased. Kwara State is situated between parallels $8 \hat{A}^{\circ}$ and $10 \hat{A}^{\circ}$ north latitudes and $3 \hat{A}^{\circ}$ and $6 \hat{A}^{\circ}$ east longitudes. The daily average temperature ranges between $21^{\circ} \mathrm{C}$ to $33^{\circ} \mathrm{C}$. The study area has two distinct climatic seasons, the wet (Rainy) and dry (Harmattan) seasons. The rainfall across the two States extends between November and February. This climatic condition as well as fertile soil makes the State favourable for arable crop production such as rice, millet, yam, cowpea etc. (KWARAMANR, 2012)

Data Collection: The data used in the study were obtained from primary sources. Data were collected using a structured-questionnaire. This questionnaire was pre-tested between June and December, 2011 for appropriateness, revised according to the feedback from the pre-testing, finalized and was thereafter re-administered to the respondents between June and December, 2012

\section{Sampling Procedure}

The target population for this study was the cultured fish farmers available to the Ministry of Agriculture, Kwara State. The study employed a random sampling procedure to select the respondents for this study. Thus a population size comprising 121 fish farmers was arrived at for the study area. A table of random numbers was used to select a pre-determined number 63 cultured fish farmers.

\section{Analytical Techniques}

The data collected for the study were analyzed using the Stochastic Frontier Production function and descriptive statistical analysis which involved the use of frequency distribution and percentages.

The Efficiency Analysis for Cultured fish farms

The implicit model employed for this study is shown as follow: $\mathrm{Y}_{\mathrm{i}}=\mathrm{f}\left(\mathrm{X}_{\mathrm{i}}: \mathrm{B}\right) \exp \left(\mathrm{V}_{\mathrm{i}}-\mathrm{U}_{\mathrm{i}}\right)$ (1) (Battese and Coelli, 1995) 
Where $Y_{i}$ is the production of the $i^{\text {th }}$ farm, $X_{i}$ is a vector of inputs used by the $i^{\text {th }}$ farm, is a vector of unknown parameters, $\mathrm{V}_{\mathrm{i}}$ is a random variable which is assumed to be independently and identically distributed (iid) $\mathrm{N} \sim\left(0,{ }_{v}{ }^{2}\right)$ and independent of $\mathrm{U}_{\mathrm{i}}$ and $\mathrm{U}_{\mathrm{i}}$ is a random variable that is assumed to account for technical inefficiency in production, Battese and Coelli (1995)

The Stochastic Frontier Production function using the Cobb -Douglas functional form was used to determine the production function in this study. This functional form has been used in other empirical studies (Izekor and Alufohai, 2014; Nosiru, Rahji, Ikpi and Adenegan, 2014; Akanbi, Omotesho, and Ayinde, 2011) to assess technical efficiencies. The production function model was explicitly specified in its linear form as:

$\ln Q_{1}=\beta_{0}+\beta_{1} \ln \left(X_{1}\right)+\beta_{2} \ln \left(X_{2}\right)+\beta_{3} \ln \left(X_{3}\right)+\beta_{4} \ln \left(X_{4}\right)+\beta_{5} \ln \left(X_{5}\right)+$ $\beta_{6} \ln \left(\mathrm{X}_{6}\right)+\beta_{7} \ln \left(\mathrm{X}_{7}\right)+\left(\mathrm{V}_{\mathrm{i}}-\mathrm{U}_{\mathrm{i}}\right)$

Where:

$i=1 \ldots n$

$Q_{i}=$ cat fish (heterobronchus spp) output $(\mathrm{kg})$

$X_{1}=$ size of pond $\left(\mathrm{m}^{2}\right)$

$X_{2}=$ labour in Man-hours

$X_{3}=$ qty of Feed used $(\mathrm{Kg})$

$X_{4}=$ number of fingerlings

$X_{5}=$ depreciated cost of equipment $(N)$

In =Natural Logarithm (i.e. Log to basee)

$\beta_{i}(s)(l=1 . . . n)=$ unknown Parameters to be estimated.

Estimation Procedure of Stochastic Frontier Functions

The maximum likelihood estimation of the stochastic production function provides estimators for $\beta$ 's variance parameters $\left(\sigma^{2}=\sigma u^{2}+\sigma v^{2}\right)$, gamma $(y)$, which is equal to $\sigma u^{2} / \sigma^{2}$, and lambda $(\lambda)=\sigma u / \sigma v$. The parameter gamma ( $\mathrm{y}$ ) has a value between zero and one (Battese and Tessama, 1993). According to Battese and Corra (1977), gamma (y) is the total output made on the frontier function which is attributed to technical efficiency. Similarly, (1- $y)$ measures the technical inefficiency of the firms. The parameter lambda $(\lambda)$ is expected to be greater than one. Such a result according to Tadesse and Krishnamoorty (1997) indicates a good fit for the model and the correctness of the specified distributional assumptions for $V_{i}$ and $U_{i}$. The distribution of the inefficiency term is very 
important to the estimation of the models. These are of three types:

-The half-normal distribution,

-The exponential distribution, and

-The truncated-normal distribution.

In most analyses, the half-normal distribution was found to out-perform the other two distributions. In this study, experimentation with the data set indicated that the half-normal distribution model best fit the data set. This distribution was therefore adopted in the subsequent analysis.

\section{Returns to Scale and Cost Efficiency}

The presence of economies of scale is computed as an inverse of the co-efficient of cost elasticities of production. The empirical implications of these relationships are

- If RTS $>1$, production is in the zone of increasing returns to scale, cost inefficiency and TCEP $<1$. A rational producer and profit maximize will try to increase output up to the optimum level.

- If RTS $=1$, at this point production is characterized by constant returns to scale, cost efficiency and TCEP $=1$. Output is at optimum and the long run profit is maximized.

- If RTS $<1$, production is in the zone of decreasing returns to scale, cost inefficiency and TCEP> 1. A rational producer and profit maximize will try to decrease output up to the optimum level.

This exposition sheds light on the relevant relationships associating the different concepts in cultured fish production and providing insights into the theoretical and empirical deductions that can be made from the results of this study. It will essentially help in the quantification of the long run total cost elasticity and the possible interpretation inherent in the findings of this study. The value additions of some of the frameworks covered in this study are that:

- Cultured fish stochastic frontier production functions could be characterized on the basis of their RTS values into one of increasing, constant and decreasing RTS.

- Cultured fish production systems could be characterized by the nature of their long run average cost (LAC) curve as operating within the decreasing or increasing zones.

- Cultured fish production in the areas of study could be categorized on the basis of cost efficiency or inefficiency, and that Cultured fish production could be characterized by its 
long run total cost elasticity of production with implications for resource- use efficiency, optimum output attainment and profit maximization objective.

In the short run, a farm/firm is handicapped by the fact that some of the inputs are fixed. In the long run, however, the firm has no such problem. It can expand or contract its output according to demand by having more or less of all the factors of production. The Cobb-Douglas production function as specified in this study depicts the long-run situation.

Cost efficiency from $T E=A E x E E$

Stochastic frontier function in the short run

$$
\begin{aligned}
E E= & \left(\frac{T E}{A E}\right) \\
\text { 1. } & T E=A E \times E E \\
& \therefore E E=(T E / A E)
\end{aligned}
$$

2. But $C E=\frac{1}{E E} ;$ EE generated from SFCF.

$$
\begin{aligned}
\therefore C E & =1 / T E / A E \\
& C E=\frac{A E}{T E} ; C E \geq 1
\end{aligned}
$$

All the factors are freely variable. As the firm expands, the nature of output and cost of production is influenced by the law of returns to scale (Sundharam and Vaish, 1979). The average and marginal output in the long-run will rise and reach a maximum point and then decline. Correspondingly, the average cost and marginal cost of production in the long-run will slope downwards; reach a minimum point and then rise. It is important to note that in the long-run, the distinction between fixed and variable cost do not hold, as all costs are variable.

\section{RESULTSAND DISCUSSION}

The socio-economic characteristics of fish farmers are presented in the attached Table 1. Of the cultured fish farmers sampled, $82.5 \%$ were male $100 \%$ had formal education and $87.3 \%$ were married; fish farming appear to be a male dominated activity in the study area. This is similar to the findings of Fijeka, et al., (2007), Esu, et al., (2009). The latter in their study found that fish farming 
was majorly a male dominated activity. This practice is not peculiar to Nigeria alone as Fijeka, et al. (2007) et al. in their study reported similar trend in China, Philippine, India and Bangladesh.

Stochastic Frontier Production Function Analysis

The maximum likelihood estimates of the parameters of the frontier models for the cultured fish farms are presented in table 2 . The table shows the estimates of regression and variance parameters. The estimate of $\lambda$ was 2.2594 and this value was significantly different from zero, indicating a good fit and correctness of the required distributional assumptions.

Table 2: Results of Stochastic Frontier Production Function for Kwara State

\begin{tabular}{lll}
\hline Variables & Parameters & t-values \\
\hline Size of Ponds $\left(\mathrm{m}^{2}\right)$ & $0.1203^{\star \star \star}$ & 4.2811 \\
Labour & $(0.0281)$ & -2.2165 \\
& $-0.1587^{\star \star}$ & \\
Qty of feed & $(0.0716)$ & 3.5485 \\
Fingerlings & $0.3765^{\star \star \star}$ & \\
& $(0.1061)$ & 7.2946 \\
Equipment & $0.5843^{\star \star \star}$ & \\
& $(0.0801)$ & 3.8622 \\
Constant & $0.3167^{\star \star \star}$ & 1.7652 \\
$\mathrm{~N}=63$ & $(0.0820)$ & \\
$\lambda=2.2594$ & 1.8642 & \\
$\mathrm{y}=0.8363$ & $(1.0561)$ & \\
$\sigma \mathrm{u}^{2}$ & & \\
$\sigma \mathrm{u}=0.4031$ \\
$\sigma \mathrm{v}^{2}$ & & \\
$\sigma \mathrm{v}=0.1783$ \\
$\sigma^{2}=0.1943$ \\
$\sigma=0.4408$ \\
log-likelihood $=0.1625$ & & \\
\hline
\end{tabular}

Note: Asterisks indicate significance. ${ }^{\star \star \star}$ Significant at $1 \%$ Level. * Significant at $5 \%$ Level.* significant at $10 \%$ level. 
The estimate of $y$ which is the ratio of the variance of farm specific technical efficiency to the total variance of output was 0.8363 . The parameter estimates for size of pond, quantity of feed fingerlings and equipment are significant at $1 \%$ level. The co-efficient of labour was significant at $5 \%$ level. All the estimated production function parameters were statistically significant in the study area. Labour however presented negative sign contrary to a priori expectations. In the cultured fish farms assessed, Labour was required for feeding ( $50 \%$ on the average), fertilizing, maintenance, stocking and harvesting. Most fish farms visited operated majorly through a combination of labour sources which often include the owner, one hired staff (in some cases) and a few other immediate family members whose labour contributions, when pooled together, suggests that labour could have been over utilized. Ogunfowora et al., (1974) suggested that over utilization of labour could be responsible for the resulting negative coefficient observed in Maximum Likelihood Estimates. This scenario he referred to as disguised unemployment. Similar results, showing negative signs for labour, were also obtained by Rahji and Falusi (2003), Adewumi et al., (2003), Sekhon et al.,(2010), Onoja and Achike (2011), Akanbi et al., (2011), Olayiwola (2013) and Jatto et al., (2013). Like Ogunfowora et al., (1974), the reasons generally adduced for this phenomenon by these researchers were that the labour input resource was over utilized.

The estimated y values presented in table 2 indicates that the difference between observed output and frontier output was due to statistical noise/variability. The table shows 0.8362 (i.e. 83.62\%) and 0.1638 (i.e. 16.38\%) for technical efficiency and inefficiency level respectively for the assessed farms. The parameter lambda $(\lambda)$ is expected to be greater that one. Such a result according to Tadesse and Krishnamoorty (1997) indicates a good fit for the model and the correctness of the specified distributional assumptions for $V_{i}$ and $U_{i \cdot}$. As a result, lambda $(\lambda)$ cannot be less or equal to one. However, if lambda $(\lambda)$ is equal to one then gamma $(y)$ is equal to 50 . It is thus only reasonable to start gamma $(\mathrm{y})$ at 51 for values of lambda $(\lambda)$ greater than one. This is more so as gamma $(\mathrm{y})$ is the same thing as Technical Efficiency. This consideration informed the use of the class intervals in the distribution of the technical efficiency scores as presented in table 3.

With a higher frequency of the assessed cultured fish farms operating between 81 and 85\% technical efficiency levels, all that is now needed is to increase the scale of production as this will tend to translate to more fish output than. 
Table 3: Technical Efficiency scores Distribution for Respondent Farms

\begin{tabular}{lcl}
\hline TE Range & Frequency & $\%$ \\
\hline $51-55$ & 3 & 4.8 \\
$56-60$ & 5 & 7.9 \\
$61-65$ & 7 & 11.1 \\
$66-70$ & 8 & 12.7 \\
$71-75$ & 10 & 15.9 \\
$76-80$ & 12 & 19.1 \\
$81-85$ & 15 & 23.8 \\
$86-90$ & 3 & 4.8 \\
$91-95$ & 0 & 0.0 \\
$96-100$ & 0 & 0.0 \\
& 63 & 100.0 \\
\hline
\end{tabular}

Assessing the economies of scale among the cultured fish farms was computed as inverse of cost elasticities with respect to fish output.The results indicated that cultured fish production process in the study area is in the zone of increasing returns. The implications of these findings are that;

- The optimum pond size or scale of production has not been attained. This indicates the need for expansion or increase in the scale of operation of the fish farms. Increasing the scale of operation will tend to translate to more fish output and a reduction in the demandsupply gap for this is one of the problems solving focus of this study. It could lead to a decline in fish importation ceteris paribus.

- The production process is not characterized by cost efficiency. To improve cost efficiency, expansion of fish output to the point of constant returns to scale is required. Table 4 also indicates that the Total Cost Elasticities of Production (TCEP) values are all less than one. Hence, a major finding of this study is that cultured fish production in the study area is characterized by long run total cost elasticity of production of less than one in all cases. The empirical implications of such a finding are that resource use efficiency, optimum output 
level and profit maximization objective of production are not attained by the production systems. This outcome calls for re-allocation or resource adjustments in cultured fish production in the study area.

Table 4: Elasticity of Production (EOPs) of Cultured Fish in the State

\begin{tabular}{ll}
\hline Variables & \\
\hline Size of Ponds $\left(\mathrm{m}^{2}\right)$ & 0.1203 \\
Labour & -0.1587 \\
Qty of feed & 0.3765 \\
Fingerlings & 0.5843 \\
Equipment & 0.3167 \\
RTS $=\sum$ EOPs & 1.2391 \\
TCEP & 0.8070 \\
\hline
\end{tabular}

\section{CONCLUSION AND RECOMMENDATIONS}

Cultured fish farming potentials in Kwara state has not been fully exploited. Though the farms assessed operated with mean Technical Efficiency (TE) of $83.62 \%$, yet the production process is not characterized by cost efficiency. Consequently, this study came up with the following recommendations that can be of help in improving upon cultured fish production in the study area: To improve cost efficiency, the re-allocation or resource adjustment and expansion of fish output to the point of constant return to scale in culture fish production in the study area is required. Increasing the scale of operation will tend to translate to more fish output and a reduction in the demand-supply gap for this is one of the problems solving focus of this study. It could lead to a decline in fish importation ceteris paribus. The study recommend that the government should also facilitate a policy of cost reduction in terms of the cost of inputs. A reduction in costs may lead to an increased output and thereby reducing the supply-demand gap for fish in the state. In addition, the fish farmers should be provided with the services of well-trained extension workers who will be there to guide them appropriately on production best practices to enable farmers improve upon farm efficiency. 


\section{REFERENCES}

Adewumi, M.O, Ayinde, O.E, Oladeinde, O.Aand Muhammed-Lawal, A(2003): "Economic Analysis of Fish Farming in Ogun State of Nigeria" Seminar paper. Fishery Society of Nigeria Conference Paper, Annual conference fishery association of Nigeria, llorin.

Akanbi, U.O., Omotesho, O.A. and Ayinde, O.E (2011): Analysis of Technical Efficiency of Rice Farms in Duku Irrigation Scheme in Kwara State, Nigeria. Nigerian Journal of Agriculture, Food and Environment 7(3):65-72

Battese,G.E. and Coelli T.J. (1995): "A model for Technical Inefficiency Effect in a Frontier Production Function for Panel Data" Journal of Empirical Economics, 20:325-332

Battese, G.E. and G.S. Corra (1977): "Estimation of a Production Frontier Model with Application to the Pastoral Zone of Eastern Australia" Journal of Agricultural Economics, 21: 169-179.

Battese, G.E. and G.A. Tessema (1993): "Estimation of Stochastic Frontier Production Function with Time-varying Parameters and Technical Efficiency using Panel Data from Indian Villages." Journal of Agricultural Economics, 9: 313-333.

Bravo-Ureta BE, Pinheiro A (1993): "Efficiency analysis of developing country Agriculture: a review of the frontier function literature". Agric Resource Econ Rev 22:88-101

Central Bank of Nigeria-CBN (2011): Central BankAnnual Statistical Bulletin

Esu, B. B., Asa, U. A. and Iniedu, M. O (2009): "Costs and Returns of Fish Production Using Earthen Ponds in Akwa Ibom State, Nigeria". Nigerian Journal of Agriculture, Food and Environment. 5(2-4):26-29.

Farrel, M. J. (1957): "Measurement of Productive Efficiency", Journal of the Rural Statistical Society: A120: 253-290. Function" Journal of Econometrics 13: 27-56

Federal Ministry of Agriculture and Rural Development -FMARD (2011): Annual progress report, 2011

Fejika, P. I., Ayanda, J. O. and Sule, A.M. (2007): "Socio-economic variables affecting Aquaculture production and practices in Borgu local government area of Niger state, Nigeria." Journal of Agriculture and social research (JASR) 7(2):34-38

Food and Agriculture Organization - FAO(2010): "The State of World Fisheries and Aquaculture"

- fao.org/fishery/topic/16064/en(d.d12/04/2012)

lyangbe, C.O and Orewa, S.I (2009), "Determinants of Daily Protein Intake among Rural and Low-income Urban Households In Nigeria", American Journal of Scientific Research 4(4): 290-301

Izekor, O.B. and Alufohai, G.O(2014), Production Elasticities, Return to Scale and Allocative Efficiency in Yam Production in Edo State, Nigeria, Agrosearch:14(2):179-190 14(2):179-190

Jatto N.A., Alkali A. ,Galadima Z. I., Gunu U.I. andMaikasuwa M.A. (2013): "Estimating the Factors Influencing Cat Fish Farmers' Interest in Fish Production in Ilorin, Kwara State."European Scientific Journal 9(13):99-106. 
Khandaker, M.R. (1998): "Production Frontier and Production Efficiency of Producing Rice in Bangladesh" (Unpublished research proposal submitted to the Department of Projecct \& Regional Planning, University of Giessen, Bangladesh).

Kwara, MANR, (2012), "KWARA Ministry of Agricultural Natural Resources: Annual Progress Report 2012"

Nosiru, O.M.O., M.A.Y. Rahii, A.E. Ikpi and K.O. Adenegan (2014), Scale Efficiency and Determinants of Productivity of New Rice for Africa (Nerica) Farmers in Kaduna State, Nigeria, Agrosearch 14(2):113-128

Ogunfowora O, Essang S.M and Olayide S.O (1974): "Resource Productivity in Traditional Agriculture: A case Study of the Four Agricultural Division in Kwara State of Nigeria" Journal of Rural Economics and Development 9(2): 119.

Olayiwola O.O (2013): "technical efficiency of fish production in ljebu-ode, Nigeria. Journal of Research In Management and Technology, 2:16-42.

Onoja, A O. and Achike, A.I. (2011): "Resource Productivity in Small-Scale Catfish (Clarias Gariepinus) Farming in Rivers State, Nigeria: A Translog Model Approach|." Journal of Agriculture and Social Research (JASR) 2: 139-146

Rahii M.A.Y and Falusi O.A(2003): "An Econometric Analysis of Fish Culture in Oyo State Nigeria." Journal of Sustainable Topical Agriculture Research. 6:85-89

Rahji M.A.Y. and Omotesho O.A. (2006): "Technical Efficiency and Competitiveness in Production: the case study of rice farmers in Niger State" Agrosearch: 8: 1-2.

Schmidt, P. (1986), "Frontier Production Functions", Econometric Review, 4, 289-328

Sekhon M.K., Amrit K.M., Manjeet K and Sidhu M.S (2010): "Technical Efficiency in Crop Production: A Region- Wise Analysis." Agricultural Economics Research Review, 23:367-374.

Sundharam, K.P.M. and M.C. Vaish (1979): "Principles of Economics." $13^{\text {th }}$ Revised and Enlarged Edition. Vikas Publishing House PVT Ltd. Vikas House, 20 / 4 Industrial Area Sahibabad Disu Ghazirabad U.P. India, 76-78.

Squires D.E., (1987), "Fishing effort: its testing, specification, and internal structure in fisheries economics and management", Journal of Environmental Economics Management, (14:268-282)

Tadesse, B. and S. Krishnamoorty (1997): "Technical Efficiency in Paddy Rice of Tamil Nadu: An Analysis based on Farm size and Ecological Zones." Agricultural Economics, 16: 185192.

World Bank (2010): "Promise and Challenges of Sustainable Aquaculture Agriculture and Rural Development". Conference proceedings paper T41694. 
Akanbi

Table 1: Socio-Economic Characteristics of Respondents (Source: Field Survey, 2012)

\begin{tabular}{|c|c|c|c|c|c|}
\hline & & Kwara Stat & & Kogi State & \\
\hline Measured Variable & & Frequency & Percent & Frequency & Percent \\
\hline Sex & Male & 52 & 82.5 & 46 & 90.2 \\
\hline & Female & 11 & 17.5 & 5 & 9.8 \\
\hline & Total & 63 & 100.0 & 51 & 100.0 \\
\hline Formal Education & Had formal & 63 & 100.0 & 44 & 86.3 \\
\hline & No formal & 0 & 0.0 & 7 & 13.7 \\
\hline & Total & 63 & 100.0 & 51 & 100.0 \\
\hline Marital Status & Single & 6 & 9.5 & 5 & 9.8 \\
\hline & Widow & 2 & 3.2 & 1 & 2.0 \\
\hline & Married & 55 & 87.3 & 45 & 88.2 \\
\hline & Total & 63 & 100.0 & 51 & 100.0 \\
\hline Age & $<35$ & 16 & 25.4 & 10 & 19.6 \\
\hline & $36-45$ & 16 & 25.4 & 20 & 39.2 \\
\hline & $>45$ & 31 & 49.2 & 21 & 41.2 \\
\hline & Total & 63 & 100.0 & 51 & 100.0 \\
\hline Years of Experience & $<6$ & 10 & 15.9 & 37 & 72.5 \\
\hline & $06-10$ & 21 & 33.3 & 7 & 13.7 \\
\hline & $11-15$ & 22 & 34.9 & 4 & 7.8 \\
\hline & $>15$ & 10 & 15.9 & 3 & 5.9 \\
\hline & Total & 63 & 100.0 & 51 & 100.0 \\
\hline Aquaculture as Main Income & No & 34 & 54 & 33 & 64.7 \\
\hline & Yes & 29 & 46 & 18 & 35.3 \\
\hline & Total & 63 & 100.0 & 51 & 100.0 \\
\hline Other Sources of & Other Agric-based & 4 & 6.3 & 11 & 21.6 \\
\hline Income & Trading & 16 & 25.4 & 13 & 25.5 \\
\hline & Salaried Job & 43 & 68.3 & 27 & 52.9 \\
\hline & Total & 63 & 100.0 & 51 & 100.0 \\
\hline Source of Fund & Money Lenders & 1 & 1.6 & 3 & 5.9 \\
\hline & Bank loan & 12 & 19.0 & 2 & 3.9 \\
\hline & Friends & 7 & 11.1 & 10 & 19.6 \\
\hline & Remittance & 2 & 3.2 & - & - \\
\hline & Personal Saving & 41 & 65.0 & 36 & 70.6 \\
\hline & Total & 63 & 100.0 & 51 & 100.0 \\
\hline
\end{tabular}

